\title{
Optimizing HIV-1 protease production in Escherichia coli as fusion protein
}

Federica Volontè ${ }^{1,2}$, Luciano Piubelli ${ }^{1,2}$ and Loredano Pollegioni ${ }^{1,2^{*}}$

\begin{abstract}
Background: Human immunodeficiency virus (HIV) is the etiological agent in AIDS and related diseases. The aspartyl protease encoded by the $5^{\prime}$ portion of the pol gene is responsible for proteolytic processing of the gag-pol polyprotein precursor to yield the mature capsid protein and the reverse transcriptase and integrase enzymes. The HIV protease ( $\mathrm{HIV}-1 \mathrm{Pr})$ is considered an attractive target for designing inhibitors which could be used to tackle AIDS and therefore it is still the object of a number of investigations.

Results: A recombinant human immunodeficiency virus type 1 protease (HIV-1Pr) was overexpressed in Escherichia coli cells as a fusion protein with bacterial periplasmic protein dithiol oxidase (DsbA) or glutathione S-transferase (GST), also containing a six-histidine tag sequence. Protein expression was optimized by designing a suitable HIV$1 \operatorname{Pr}$ CDNA (for E. coli expression and to avoid autoproteolysis) and by screening six different E. coli strains and five growth media. The best expression yields were achieved in E. coli BL21-Codon Plus(DE3)-RIL host and in TB or M9 medium to which $1 \%(\mathrm{w} / \mathrm{v})$ glucose was added to minimize basal expression. Among the different parameters assayed, the presence of a buffer system (based on phosphate salts) and a growth temperature of $37^{\circ} \mathrm{C}$ after adding IPTG played the main role in enhancing protease expression (up to $10 \mathrm{mg}$ of chimeric DsbA:HIV-1Pr/L fermentation broth). GST:HIVPr was in part (50\%) produced as soluble protein while the overexpressed DsbA:HIV$1 \operatorname{Pr}$ chimeric protein largely accumulated in inclusion bodies as unprocessed fusion protein. A simple refolding procedure was developed on HiTrap Chelating column that yielded a refolded DsbA:HIV-1Pr with a > 80\% recovery. Finally, enterokinase digestion of resolubilized DsbA:HIV-1Pr gave more than $2 \mathrm{mg}$ of HIV-1Pr per liter of fermentation broth with a purity $\leq 80 \%$, while PreScission protease cleavage of soluble GST:HIVPr yielded $\sim 0.15$ mg of pure HIV-1Pr per liter.
\end{abstract}

Conclusions: By using this optimized expression and purification procedure fairly large amounts of good-quality HIV-1Pr recombinant enzyme can be produced at the lab-scale and thus used for further biochemical studies.

\section{Background}

Retroviral proteins are synthesized as polyprotein precursors, which are subsequently processed by specific proteases. The aspartyl protease encoded by the human immunodeficiency virus (HIV) plays an essential role in viral maturation and is considered an attractive target for the treatment of acquired immunodeficiency syndrome (AIDS). The HIV-1 protease (HIV-1Pr) is encoded by the 5 ' portion of the pol gene and is responsible for processing the $g a g$ and gag-pol polyproteins to

\footnotetext{
* Correspondence: loredano.pollegioni@uninsubria.it

'Dipartimento di Biotecnologie e Scienze Molecolari, Università degli Studi dell'Insubria, via J.H. Dunant 3, Varese, 21100, Italy Full list of author information is available at the end of the article
}

yield mature capsid proteins and the enzymes protease, reverse transcriptase, and integrase [1].

In the past, HIV-1Pr was synthesized chemically [2] or expressed by recombinant DNA technology in various heterologous systems [3]. In order to produce large amounts of HIV-1Pr, different strategies were investigated: i) it was produced by autocatalytic processing of a larger precursor $[4,5]$; ii) it was fused to a variety of proteins, e.g., $\beta$-lactamase [6], glutathione $S$-transferase (GST), maltose-binding protein [7], N-terminal portion of $\gamma$-interferon [8], or as His-tagged recombinant protein [9]; iii) codon usage, A+T richness at the 5 ' end of the coding region, and the promoter were optimized [10,11]; and iv) it was recovered by refolding of $E$. coli inclusion bodies [12,13]. Owing to the cytotoxicity (and low
C Biomed Central 
solubility) of this protease, it is difficult to obtain it in large quantities: in most cases the expression level was low and the recombinant HIV-1Pr could be detected only by immunoblotting (see Additional file 1, Table S1). After about 20 years of investigations, HIV-1Pr is still considered an important target for developing new drugs to cope with AIDS. Recently, for example, peptides displaying a sequence identical to those segments of the HIV-1Pr monomers associated with the local elementary structures, LES, have been proposed to destabilize the native structure of the protease. These new inhibitors may have a high genetic barrier for resistance as they bind HIV-1Pr through highly conserved residues which play an essential role in the protein folding process. The properties of promising inhibitors of HIV-1Pr monomer folding were investigated with the help of spectrophotometric assays and circular dichroism spectroscopy [14]. Unfortunately, these studies require milligram quantities of the viral protein in the soluble and active form and its commercial cost represents a main limit for academic studies.

The purpose of this study therefore was to construct a high and reproducible expression system for HIV-1Pr and to establish a convenient (simple and fast) purification procedure for obtaining fairly large amounts of the corresponding recombinant active protein at the labscale. In this paper we describe two new methods for obtaining HIV-1Pr that were established by producing different chimeric proteins, but also by optimizing both the expression in $E$. coli (mainly by acting on host strain selection and on medium composition) and the purification and maturation processes.

\section{Results and Discussion \\ Expression of DsbA:HIV-1Pr}

A synthetic cDNA encoding for a variant HIV-1Pr was designed to optimize codon usage for protein expression in $E$. coli and to avoid autoproteolysis and disulfide bridge formation (Additional file 1, Figure S1) [15]. Preliminary trials focused on the expression of untagged HIV-1Pr (by using pET24b(+) and pET26b(+) plasmids): in no case was HIV-1Pr expressed to a detectable level (see Additional file 1, Supplementary text).

The synthetic cDNA was then cloned in pET39b(+) plasmid. In this way, a chimeric protein could be produced that was constituted by the target protease fused with the full-length $E$. coli periplasmic dithiol-oxidase DsbA protein (Additional file 1, Figure S1A). Under standard conditions - i.e., BL21(DE3)pLysS cells induced at the early-exponential phase of growth and cell recovery after 1 hour of incubation at $37^{\circ} \mathrm{C}$ after adding IPTG - approx. $0.7 \mathrm{mg}$ of DsbA:HIV-1Pr is produced per liter of fermentation broth.

Expression trials were then carried out in LB medium containing $1 \%(\mathrm{w} / \mathrm{v})$ glucose, growing the cells at $37^{\circ} \mathrm{C}$ and using different E. coli strains: BL21(DE3)pLysS, BL21-Codon Plus(DE3)-RIL, BL21-Star(DE3), C41(DE3), C41(DE3)pLysS, C43(DE3), C43(DE3)pLysS, and KRX (Figure 1) [16,17]. The BL21-Codon Plus(DE3)-RIL strain supplies extra copies of tRNA genes that are rare in E. coli; the BL21-Star(DE3) host strain allows good basal expression of the heterologous genes, mainly because of an increased stability of mRNA molecules, while C41, C43, and KRX E. coli strains are suitable for toxic heterologous protein expression because of a resistance to toxic proteins ( $\mathrm{C} 41$ and $\mathrm{C} 43$ strains) or of a very stringent control of basal expression (KRX strain) $[16,17]$. At the same time, the effect of the time point of protein induction was also investigated by adding IPTG at the early-, middle-exponential, or stationary growth

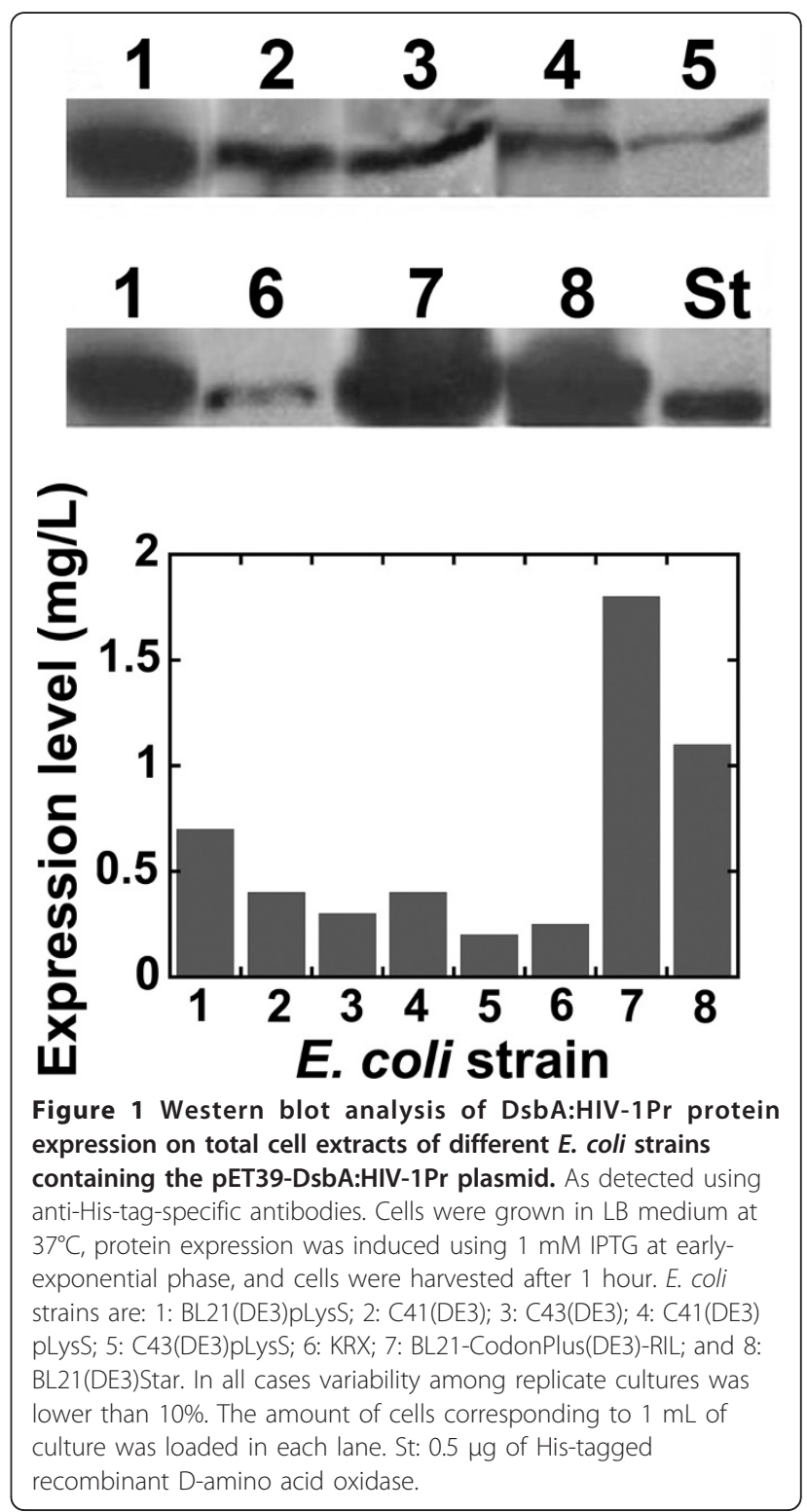


phase. Western blot analysis using anti-His-tag-specific antibodies on total cell extracts showed the highest DsbA:HIV-1Pr expression level for the BL21-Codon Plus(DE3)-RIL strain (Figure 1) and when IPTG was added at the middle-exponential phase of growth (see results in Figure 2B and 2D). Substantial expression of DsbA:HIV-1Pr chimeric protein was also observed by inducing protein synthesis at the early-exponential phase of growth, whereas no HIV-1Pr-associated signal was observed by adding IPTG at the stationary phase (Figure 2). In all cases, the recombinant fusion protein largely accumulated as inclusion bodies: a semi-quantitative analysis carried out by means of Western blot on the soluble fraction and the cell pellets estimated that $80 \%$ of the expressed fusion protein is present in the insoluble fraction (see Figure 3A for cells grown in TB medium). On the basis of these results, subsequent investigations were carried out to optimize DsbA:HIV1Pr expression using the BL21-Codon Plus(DE3)-RIL E. coli strain.

At first, the effect of cultivation medium composition both on the growth of recombinant BL21-Codon Plus (DE3)-RIL cells carrying the pET39-DsbA:HIV-1Pr plasmid and on the production of the chimeric protein was investigated. Cells grown in 5 different media (each of them added with $1 \%(\mathrm{w} / \mathrm{v})$ glucose, see above) at $37^{\circ} \mathrm{C}$ were analyzed using the Gompertz equation (Additional file 1, Figure S2) [18]. The highest amount of cell paste (about $7.5 \mathrm{~g}$ of cells/L culture) was achieved in TB and SB media. Concerning HIV-1Pr production, protein expression was induced by adding $1 \mathrm{mM}$ IPTG at cells grown on different media at the early- or middle-exponential phase (based on the growth curves as reported in Additional file 1, Figure S2); cell samples were withdrawn up to 3 hours after induction. Basal expression of recombinant chimeric HIV-1Pr (i.e., before adding IPTG) was observed only in SB medium. In all cases, the protein expression increased with time; the highest levels of DsbA:HIV-1Pr expression were obtained in TB and M9 medium and collecting the cells 3 hours after adding IPTG at the middle-exponential phase of growth (Figure 2).

The effect of medium composition on DsbA:HIV-1Pr production and the observation that a significant decrease in $\mathrm{pH}$ value was apparent during growth for all media, with the only exception of TB medium, suggest a positive role of the buffer system (based on phosphate salts) for increasing the expression yield. To test this hypothesis, cultures were grown in LB medium to which the same concentration of phosphate salts was added as present in TB or M9 media $(\sim 70 \mathrm{mM})$. Western blot analysis of total cell extracts showed a statistically significant increase in total DsbA:HIV-1Pr expression in the presence of phosphate salts, up to 2 -fold vs. standard LB medium (Figure 3B, C).
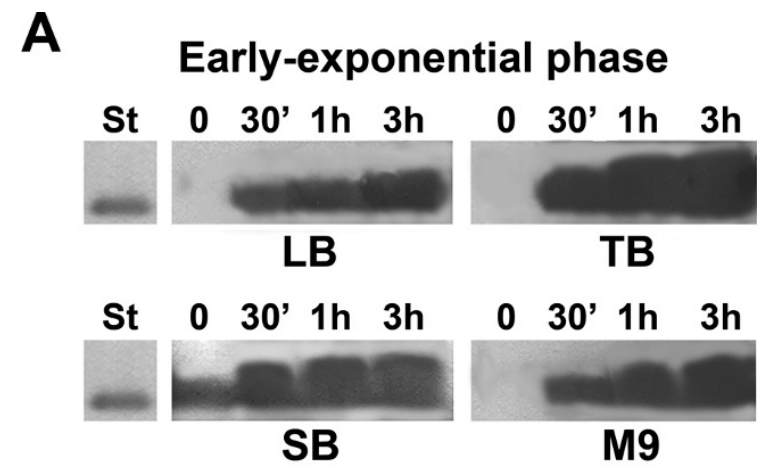

B

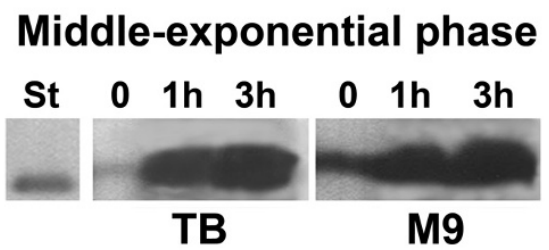

C

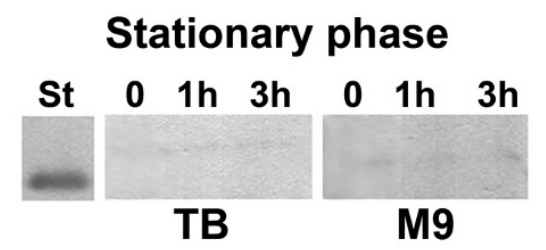

D

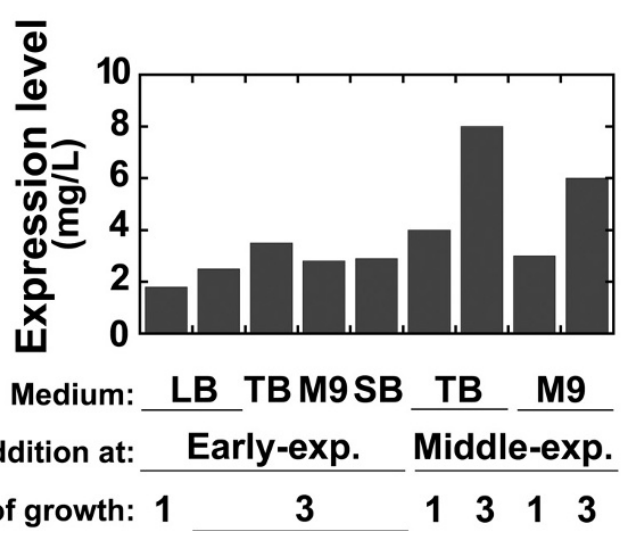

Figure 2 Western blot analysis of DsbA:HIV-1Pr expression on total cell extracts of BL21-Codon Plus-(DE3)-RIL E. coli cells containing the pET39-DsbA:HIV-1Pr plasmid and using different cultivation media. (Indicated below each panel): the cells were collected at different times after adding $1 \mathrm{mM}$ IPTG $(0,0.5,1$, or 3 hours, as indicated above each lane). Protein expression induced at A) the early-exponential phase, B) the middleexponential phase, and C) the stationary phase. An amount of cells corresponding to $1 \mathrm{~mL}$ (panel A) or $0.5 \mathrm{~mL}$ (panels $B$ and C) of culture was loaded in each lane. D) Comparison of DsbA:HIV-1Pr production level obtained using different growth conditions. The first bar represents the best conditions identified using different $E$. coli strains (see Figure 1). In all cases variability among replicate cultures was lower than 10\%. DsbA:HIV-1Pr expression was detected using anti-His-tag-specific antibodies. St: $0.5 \mu \mathrm{g}$ of His-tagged recombinant D-amino acid oxidase. 


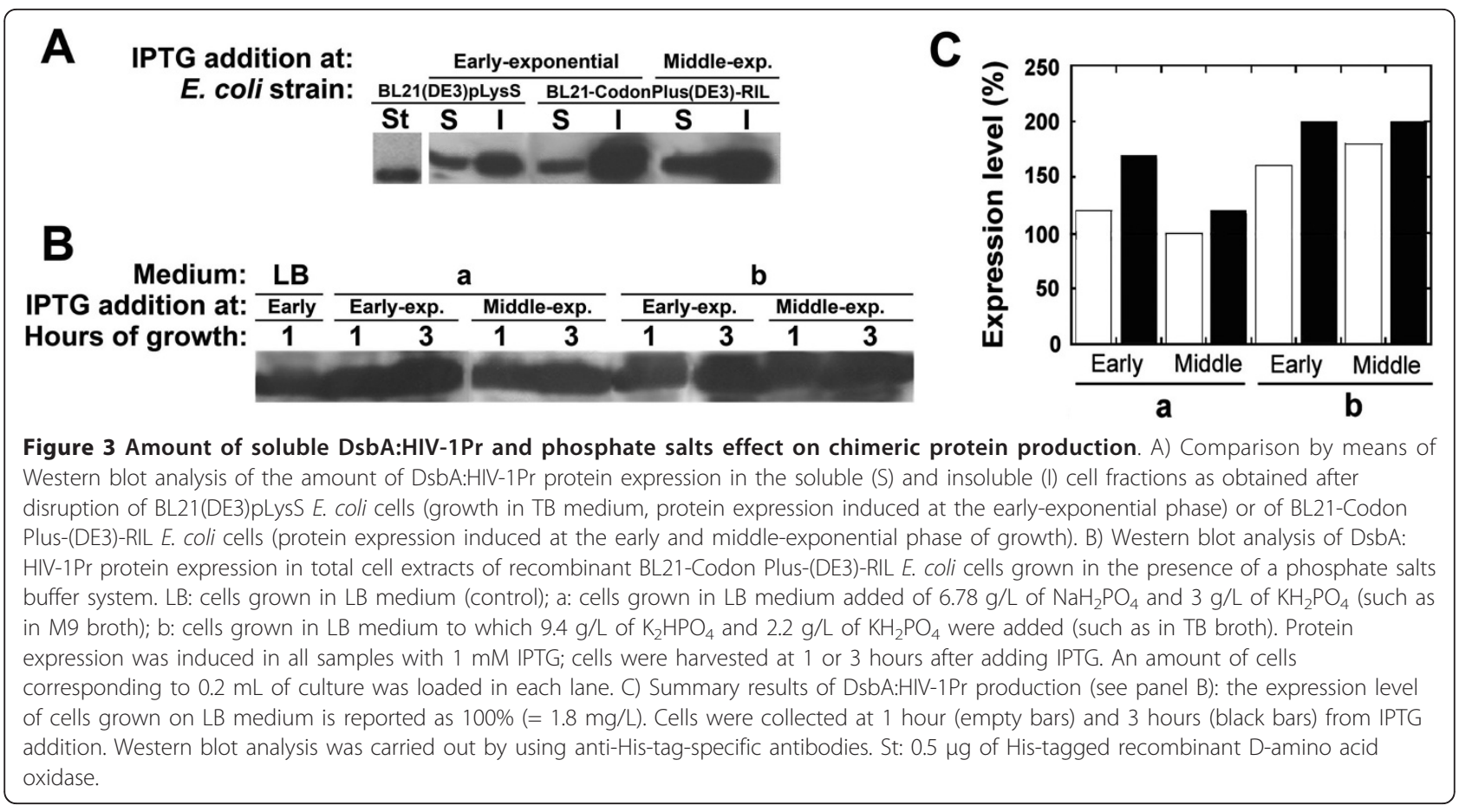

Finally, growth temperature can also affect the expression and the solubility of heterologous (recombinant) proteins expressed in E. coli [19]. Thus, the expression of DsbA:HIV-1Pr in cells grown in TB or M9 medium at 25,37 , and $42^{\circ} \mathrm{C}$ after adding IPTG was analyzed (Figure 4). The temperature did not affect the (in)solubility of the fusion protein: in all cases most of the expressed protein accumulated as inclusion bodies. Indeed, the highest level of total protein expression was observed growing at $37^{\circ} \mathrm{C}$ after adding IPTG at the middle-exponential growth phase.

The aggregated data show that the best conditions for lab-scale production of DsbA:HIV-1Pr are the use of $E$. coli BL21-Codon Plus(DE3)-RIL cells transformed with the pET39-DsbA:HIV-1Pr plasmid, grown at $37^{\circ} \mathrm{C}$ in TB or M9 medium, to which $1 \%(\mathrm{w} / \mathrm{v})$ glucose has been added, induced during the middle-exponential phase, and collected after 3 hours (up to $10 \mathrm{mg}$ of total chimeric protein/L).

\section{Purifying DsbA:HIV-1Pr fusion protein}

The recombinant DsbA:HIV-1Pr was recovered from inclusion bodies using a specific solubilization and refolding procedure. Unsoluble material obtained from cell disruption was first washed twice with $2 \mathrm{M}$ urea and $2 \%(\mathrm{v} / \mathrm{v})$ Triton X-100, followed by a washing step with the same buffer without urea. Inclusion bodies were then solubilized using $6 \mathrm{M}$ guanidium chloride under mild alkaline conditions ( $\mathrm{pH}$ 8.0) in the presence of 2-mercaptoethanol as reducing agent and loaded on a
HiTrap Chelating column previously equilibrated in the same buffer; the presence of $0.5 \mathrm{M} \mathrm{NaCl}$ and a low concentration of imidazole in the binding buffer reduces nonspecific interactions with the chromatographic matrix [20]. The refolded DsbA:HIV-1Pr was eluted, increasing the imidazole concentration up to $0.5 \mathrm{M}$. Lastly, a dialysis protocol comprising three different buffers was set up: at first the $\mathrm{pH}$ was decreased (from 8 to 7.5 ) and imidazole and EDTA concentrations were lowered, followed by a further decrease in $\mathrm{pH}$ (to 6.8) and imidazole, EDTA, and NLS concentrations, and finally equilibrating DsbA:HIV-1Pr in the storage buffer at $\mathrm{pH}$ 6.0, containing $5 \mathrm{mM}$ EDTA, $0.01 \%$ Triton $\mathrm{X}-100,10 \%$ $(\mathrm{v} / \mathrm{v})$ glycerol, and $1 \mathrm{mM} 2$-mercaptoethanol. In order to avoid precipitation/aggregation of the fusion protein, it is mandatory to change the $\mathrm{pH}$ gradually and to remove imidazole, EDTA, and NLS: dialysis of solubilized DsbA: HIV-1Pr against the storage buffer results in loss (precipitation) of a large part of the purified protein. By using this purification procedure the DsbA:HIV-1Pr fusion protein can be recovered with a purity grade higher than $95 \%$ (Figure 5A) and a $>80 \%$ recovery. Purification yield was about $8 \mathrm{mg}$ and $6 \mathrm{mg}$ of fusion protein/L culture for cells grown in TB or M9 media, respectively.

After dialysis, DsbA:HIV-1Pr fusion protein $(\sim 1 \mathrm{mg} / \mathrm{mL})$ was digested with two different commercial enterokinases, as described in Methods section: in both cases full cleavage of DsbA:HIV-1Pr was achieved (Figure 5A). Despite the fact that different chromatographic methods (ionexchange, PhenylSepharose, HiTrap chelating, etc.) were 


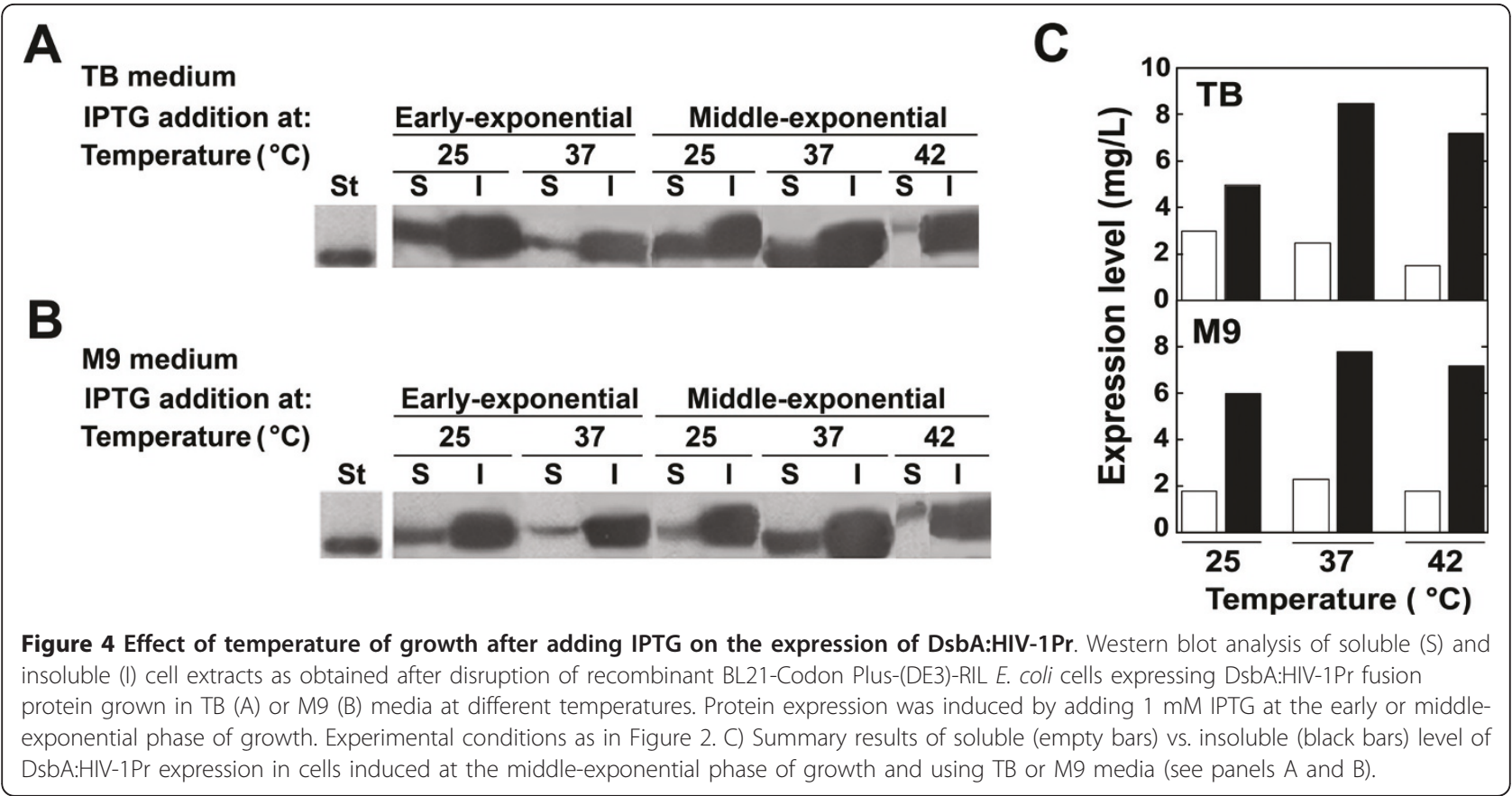

used, the DsbA and HIV-1Pr proteins were never fully separated. The best resolution was achieved by gel-permeation chromatography on Superdex 75, reaching a $\leq$ $80 \%$ of HIV-1Pr purity and an overall yield of $\sim 2 \mathrm{mg}$ HIV1 Pr per liter of fermentation broth. The activity of the purified HIV-1Pr was assayed on substrate III (Bachem), yielding a specific activity of $1.1 \mu \mathrm{mol} / \mathrm{min} \mathrm{mg}$ protein. Indeed, the purified sample was fully stable at $-20^{\circ} \mathrm{C}$ : no change in enzymatic activity was observed for up to 6 months.

\section{Expression of GST:HIVPr and HIV-1Pr purification}

BL21-CodonPlus(DE3)-RIL E. coli cells transformed with pGST:HIV or pGST:HIV-His plasmids (see Additional file 1, Figure S1), grown in LB or TB broth (supplemented of $1 \%$ glucose) at $37^{\circ} \mathrm{C}$, and to which $1 \mathrm{mM}$ IPTG was added at the beginning of the exponential phase of growth $\left(\mathrm{OD}_{600 \mathrm{~nm}} \sim 1\right.$ or $\sim 1.8$ for $\mathrm{LB}$ or $\mathrm{TB}$, respectively) produced approx. $0.5 \mathrm{mg}$ of soluble fusion protein per liter of fermentation broth, corresponding to $50 \%$ of the overall chimeric protein produced. Soluble GST:HIVPr and GST:HIVPr-His proteins were purified from the crude extract on a GSTrap column as described in the Methods section together with the free GST protein (see Additional file 1, Figure S3), suggesting an automaturation of the chimeric protein. On the contrary, when the His-tag was located at the N-terminal end of the fusion protein by using the plasmid pHis-GST:HIV, the His-GST:HIVPr fusion protein was fully accumulated as inclusion bodies up to $\sim 5 \mathrm{mg}$ of chimeric protein/L fermentation.
By performing the refolding of both GST:HIVPr-His and His-GST:HIVPr fusion proteins from inclusion bodies on the HiTrap affinity column (see Methods section), $\sim 0.7 \mathrm{mg}$ and $5 \mathrm{mg}$ of protein per liter of fermentation could be isolated, respectively. The refolded GST: HIVPr-His sample contained substantial amounts of GST protein, exactly as happens for the soluble cellular fraction (Additional file 1, Figure S3). Indeed, this enzyme preparation was not cleaved by PreScission protease (both using the on- or the off-column procedure), thus preventing the obtainment of pure HIV-1Pr.

Concerning the isolation of HIV-1Pr from the chimeric proteins by PreScission protease treatment, the best result was obtained using the GST:HIVPr or GST: HIVPr-His soluble forms by on-column cleavage. The protein eluted in peak 1 of GSTrap column showed a high degree of purity ( $\geq 90 \%$ as judged by SDS-PAGE, Figure $5 \mathrm{~B}$ ), while the sample in peak 2 partly coeluted with the fusion partner GST because of the high HIV1 Pr hydrophobicity. An overall yield of $\geq 0.15 \mathrm{mg}$ of pure HIV-1Pr/liter of fermentation broth was achieved (starting from $0.5 \mathrm{mg}$ of the fused protein/liter). The activity of the purified HIV-1Pr was assayed on substrate III (Bachem), yielding a specific activity of 1.22 $\mu \mathrm{mol} / \mathrm{min} \mathrm{mg}$ protein. The Far-UV CD spectrum of the purified protease showed a $\sim 30 \% \beta$-sheet content (Figure $5 \mathrm{C}$ ), as previously reported for folded HIV-1Pr [14].

\section{Conclusions}

HIV-1Pr has been prepared by chemical synthesis [2] or as recombinant protein from $E$. coli cells, as reported by 


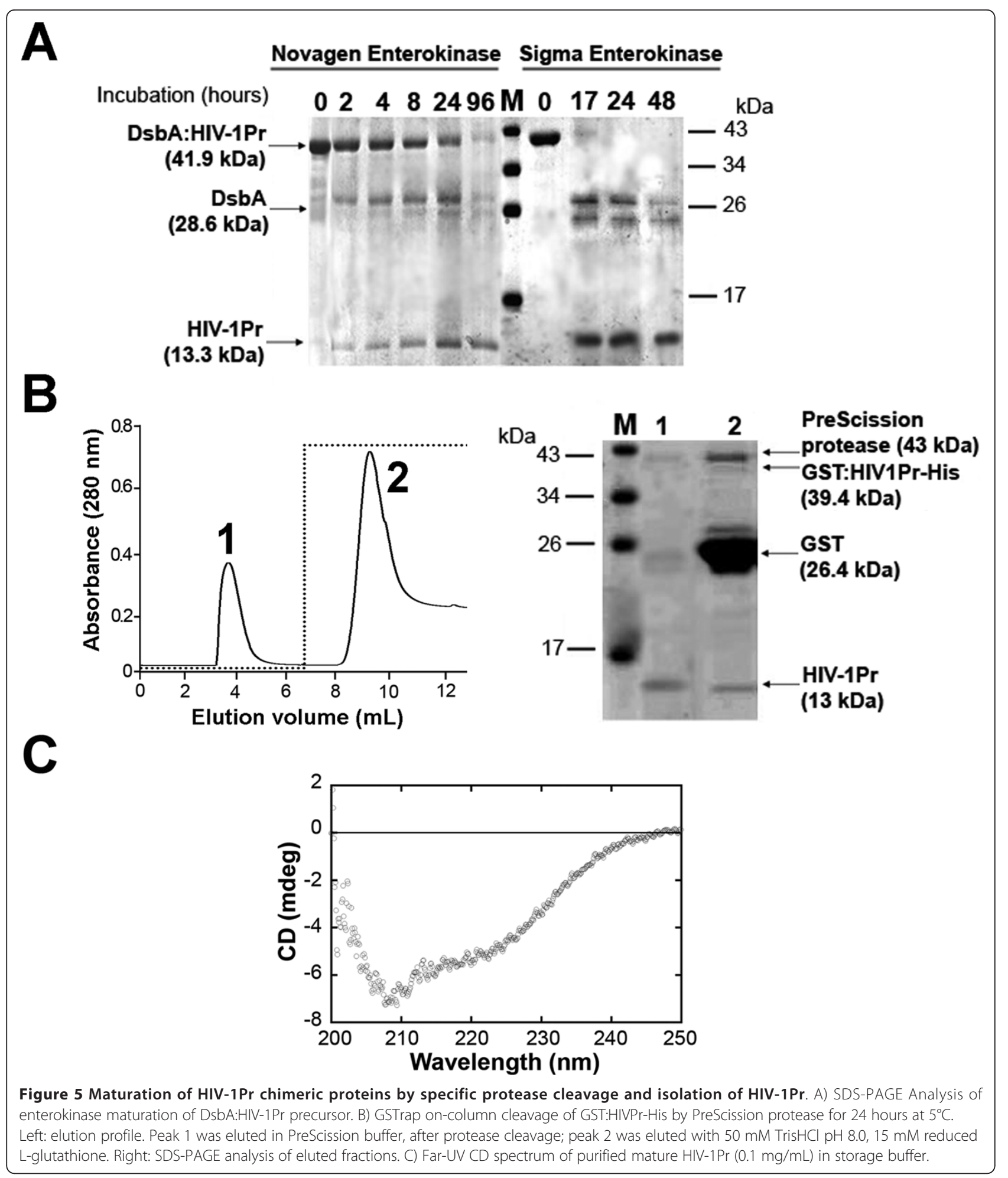

several groups [3-13]. In general the yield of purified, active HIV-1Pr from recombinant E. coli systems has been relatively low ( $\leq 1 \mathrm{mg}$ protein/L broth, see Additional file 1, Table S1) and required complex purification procedures involving multiple chromatographic steps.
Indeed, the procedures that resulted in higher expression yields (20-30 $\mathrm{mg}$ protein/L) suffered from low reproducibility [11-13]. In order to avoid cell death, overexpressed HIV-1Pr was also protein encapsulated with an engineered lumazine synthase capsid [21]. The difficulties in 
expressing recombinant $\mathrm{HIV}-1 \mathrm{Pr}$ are also made apparent by its high commercial cost ( 25,000 €/mg protein). In the present paper, we report on a systematic investigation of HIV-1Pr expression in E. coli based on the combination of gene design, expression vector, and $E$. coli strain selection, and analysis of fermentation broth and conditions. The simple purification and processing procedure described in this work resulted in the production of $\geq 2$ $\mathrm{mg}$ of $\mathrm{HIV}-1 \mathrm{Pr} / \mathrm{L}$ with a $~ 80 \%$ purity following enterokinase digestion of resolubilized DsbA:HIV-1Pr and gelpermeation chromatography, or $\sim 0.15 \mathrm{mg} \mathrm{HIV-1Pr/L}$ with a very high purity degree following PreScission protease cleavage of soluble GST:HIVPr and GSTrap chromatography purification.

In both cases, the purified HIV-1Pr retained its enzymatic activity and conformation (see Figure $5 \mathrm{C}$ for pure HIV-1Pr): these protease preparations represent a suitable tool to be employed at the academic level to investigate new strategies to tackle AIDS, i.e., for analyzing the potentialities of new classes of HIV-1Pr inhibitors [14]. This robust and reliable process for producing HIV-1Pr at lab-scale can eventually be scaled up to major volumes.

\section{Methods}

Design, synthesis, and cloning of cDNA coding for mature HIV protease

Synthetic cDNA coding for mature HIV-1Pr was designed by in silico back translation of the amino acid sequence reported in the database (GenBank Accession no. K03455). In order to eliminate autoproteolysis and to avoid disulfide bridge formation, four substitutions (Q7K, L33I, L63I and C95A) were inserted in the primary sequence (see Additional file 1, Figure S1) [15]. Synthetic cDNA was produced by Eurofins Medigenomix GmbH (Ebersberg, Germany), after optimizing the coding nucleotide sequence for expression in $E$. coli. The cDNA molecule was cloned into pET24b(+), pET26b(+), and pET39b(+) expression plasmids (Novagen, Madison, Wisconsin, USA) using NcoI (site introduced by PCR) and XhoI restriction sites. By cloning in $\mathrm{pET} 39 \mathrm{~b}(+)$ the target protein can be expressed as a fusion protein with the $E$. coli periplasmic protein dithiol oxidase (DsbA). An additional 6-residue C-terminal His-tag encoding sequence is also present in the resulting pET39-DsbA:HIV-1Pr plasmid.

The HIV-1Pr cDNA was also cloned in pGEX-6P-2 plasmid (GE Healthcare) using BamHI (site introduced by PCR) and XhoI restriction sites, giving the pGST:HIV expression vector. Two variants of this plasmid were further prepared: pGST:HIV-His, obtained using a specific PCR primer containing the 6-histidine codons before the XhoI cleavage site, and the pHis-GST:HIV vector prepared by mutagenesis using pGST:HIV as plasmid template and the primers HISGST_up (5'- CACACAGGAAACAGTATTCATGCATCACCATCACCATCA CATGTCCCCTATACTAGG -3') and HISGST_dw (5'CCTAGTATAGGGGACATGTGATGGTGATGGT GATGCATGAATACTGTTTCCTGTGTG -3’).

\section{Strain, growth conditions, and enzyme expression}

For protein expression, plasmids containing the HIV-1Pr cDNA were transferred into different $E$. coli strains: BL21(DE3)pLysS (Novagen, Madison, Wisconsin, USA), BL21-Codon Plus(DE3)-RIL (Stratagene, La Jolla, California, USA), BL21-Star(DE3) (Invitrogen, Carslbad, California, USA), KRX (Promega, Madison, Wisconsin, USA), and C41(DE3), C41(DE3)pLysS, C43(DE3), C43 (DE3)pLysS (Lucigen, Middleton, Wisconsin, USA) host cells. Starter cultures were prepared using a single colony of $E$. coli cells carrying the recombinant plasmids in LB medium containing $1 \%(\mathrm{w} / \mathrm{v})$ glucose and appropriate antibiotics: kanamicin $(30 \mu \mathrm{g} / \mathrm{mL}$ final concentration) and chloramphenicol (34 $\mu \mathrm{g} / \mathrm{mL}$ final concentration, only for BL21-Codon Plus(DE3)-RIL cells and for pLysS carrying strains) under vigorous shaking at $37^{\circ} \mathrm{C}$. The following media were used [22,23]: LuriaBertani (LB, $10 \mathrm{~g} / \mathrm{L}$ bacto-tryptone, $5 \mathrm{~g} / \mathrm{L}$ yeast extract, $5 \mathrm{~g} / \mathrm{L} \mathrm{NaCl}$ ); Terrific Broth (TB, $12 \mathrm{~g} / \mathrm{L}$ bacto-tryptone, $24 \mathrm{~g} / \mathrm{L}$ yeast extract, $8 \mathrm{~mL} / \mathrm{L}$ glycerol, $2.2 \mathrm{~g} / \mathrm{L} \mathrm{KH}_{2} \mathrm{PO}_{4}$, $9.4 \mathrm{~g} / \mathrm{L} \mathrm{K}_{2} \mathrm{HPO}_{4}$, corresponding to $70 \mathrm{mM}$ total phosphate concentration); Super Broth (SB, 32 g/L bactotryptone, $20 \mathrm{~g} / \mathrm{L}$ yeast extract, $5 \mathrm{~g} / \mathrm{L} \mathrm{NaCl}$ ); 99 minimal medium $\left(0.5 \mathrm{~g} / \mathrm{L} \mathrm{NaCl}, 1 \mathrm{~g} / \mathrm{L} \mathrm{NH} \mathrm{NH}_{4} \mathrm{Cl} 3 \mathrm{~g} / \mathrm{L} \mathrm{KH}_{2} \mathrm{PO}_{4}\right.$, $6.78 \mathrm{~g} / \mathrm{L} \mathrm{Na}_{2} \mathrm{HPO}_{4}$, corresponding to $68 \mathrm{mM}$ total phosphate concentration, $2 \mathrm{mM} \mathrm{MgSO} 4,0.1 \mathrm{mM} \mathrm{CaCl}_{2}, 10$ $\mathrm{g} / \mathrm{L}$ glucose). Baffled (500 mL) Erlenmeyer flasks containing $100 \mathrm{~mL}$ of the different media were inoculated with the starter culture (initial $\mathrm{OD}_{600 \mathrm{~nm}}=0.05$ ) and cells were grown at various temperatures with shaking (180 rpm). Protein expression was induced by adding 1 mM IPTG at different phases of the growth curve, as indicated in each case. Cells were harvested $30 \mathrm{~min}, 1$ hour, or 3 hours after induction by centrifugation at $8000 \mathrm{~g}$ for $10 \mathrm{~min}$ at $4^{\circ} \mathrm{C}$. For protein purification trials, the cultures were prepared in $2 \mathrm{~L}$ Erlenmeyer flasks containing $700 \mathrm{~mL}$ of TB medium, inoculated with the starter culture (initial $\mathrm{OD}_{600 \mathrm{~nm}}=0.05$ ), and cells grown at $37^{\circ} \mathrm{C}$ with shaking (180 rpm). Enzyme expression was induced by adding $1 \mathrm{mM}$ IPTG at the middle-exponential phase and cells were harvested as described above 3 hours after adding the inducer. In all cases, cells were stored at $-20^{\circ} \mathrm{C}$.

For Dsb:HIV-1Pr purification, crude extracts were prepared by sonication (3-4 cycles of $30 \mathrm{~s}$ each, with a 30-s interval) on ice in $20 \mathrm{mM}$ Tris $\mathrm{HCl} \mathrm{pH} 8.0,1 \mathrm{mM} 2$ mercaptoethanol, $1 \mathrm{mM}$ phenylmethylsulfonylfluoride, and $10 \mu \mathrm{g} / \mathrm{mL}$ deoxyribonuclease I (3 mL/g cells). 
Samples were centrifuged at $34500 \mathrm{~g}$ for $45 \mathrm{~min}$ at $4^{\circ} \mathrm{C}$. As concerns the E. coli BL21-CodonPlus(DE3)-RIL cells transformed with pGST:HIV, pHis-GST:HIV, or pGST: HIV-His, the soluble fraction containing the fusion proteins was recovered by sonication on ice in $\mathrm{PBS}$ pH 7.4 (140 mM NaCl, $2.7 \mathrm{mM} \mathrm{KCl,} 10 \mathrm{mM} \mathrm{Na}{ }_{2} \mathrm{HPO}_{4}, 1.8$ $\mathrm{mM} \mathrm{KH_{2 }} \mathrm{PO}_{4}$ ), containing $1 \mathrm{mM}$ phenylmethylsulfonylfluoride and $10 \mu \mathrm{g} / \mathrm{mL}$ deoxyribonuclease I $(2.5 \mathrm{~mL} / \mathrm{g}$ cells). After sonication, $1 \%(\mathrm{v} / \mathrm{v})$ Triton-X 100 was added to the sample and it was incubated for $30 \mathrm{~min}$ at $4{ }^{\circ} \mathrm{C}$ with mild shaking. Samples were centrifuged at $34500 \mathrm{~g}$ for $45 \mathrm{~min}$ at $4^{\circ} \mathrm{C}$ and the soluble fraction (crude extract) was loaded on a GSTrap column.

\section{Solubilizing and purifying DsbA:HIV-1Pr to remove inclusion bodies}

The insoluble fraction of E. coli cells expressing DsbA: HIV-1Pr after sonication (containing the inclusion bodies) was resuspended in $20 \mathrm{mM}$ Tris $\mathrm{HCl} \mathrm{pH} \mathrm{8.0,} 0.5$ $\mathrm{M} \mathrm{NaCl}, 2 \mathrm{M}$ urea, and 2\% (v/v) Triton X-100 (3 mL/g cells) and was sonicated (5 cycles of $10 \mathrm{~s}$ each, with $30-\mathrm{s}$ intervals) and centrifuged ( $34500 \mathrm{~g}$ for $45 \mathrm{~min}$ at $4^{\circ} \mathrm{C}$ ); this procedure was repeated twice. The pellet was then resuspended in $20 \mathrm{mM}$ TrisHCl, $\mathrm{pH} 8.0,0.5 \mathrm{M} \mathrm{NaCl}$, and $2 \%$ $(\mathrm{v} / \mathrm{v})$ Triton X-100 (3 mL/g cells) and centrifuged as above. The final pellet (inclusion bodies) was resuspended in $20 \mathrm{mM}$ TrisHCl pH 8.0, 0.5 M NaCl, $5 \mathrm{mM}$ imidazole, $6 \mathrm{M}$ guanidium chloride, and $1 \mathrm{mM}$ 2-mercaptoethanol ( $4 \mathrm{~mL} / \mathrm{g}$ cells) and solubilized by gently shaking it for 1 hour at room temperature [20]. Samples were centrifuged at $34500 \mathrm{~g}$ for $15 \mathrm{~min}$ at $4^{\circ} \mathrm{C}$. The surnatant was filtered through a nonsterile Millex filter (pore size: $0.45 \mu \mathrm{m}$ ) (Millipore, Bedford, Massachussets, USA) and loaded on a HiTrap Chelating column (GE Healthcare, Uppsala, Sweden) containing $\mathrm{Ni}^{2+}$ and equilibrated in $20 \mathrm{mM}$ Tris $\mathrm{HCl} \mathrm{pH} 8.0,0.5 \mathrm{M} \mathrm{NaCl}, 5 \mathrm{mM}$ imidazole, $6 \mathrm{M}$ guanidium chloride, and $1 \mathrm{mM}$ 2-mercaptoethanol. The column was then extensively washed with the same buffer and subsequently with $20 \mathrm{mM}$ TrisHCl pH 8.0, 0.5 $\mathrm{M} \mathrm{NaCl}, 20 \mathrm{mM}$ imidazole, $6 \mathrm{M}$ urea, $0.1 \%$ (w/v) N-lauroyl-sarcosine (NLS), and $1 \mathrm{mM} 2$-mercaptoethanol. The fusion protein was then refolded by slowly removing urea with a linear gradient (from 6 to $0 \mathrm{M}$ ) in 30-fold column volumes, and then eluted from the column using $20 \mathrm{mM}$ Tris $\mathrm{HCl} \mathrm{pH}$ 8.0, $0.5 \mathrm{M}$ imidazole, 0.1\% (w/v) NLS, 50 $\mathrm{mM}$ EDTA, and $5 \mathrm{mM} 2$-mercaptoethanol [20]. The eluted protein was dialyzed against the following buffers (1 hour each): $20 \mathrm{mM}$ TrisHCl pH 7.5, $0.1 \mathrm{M}$ imidazole, $0.1 \%(\mathrm{w} / \mathrm{v})$ NLS, $20 \mathrm{mM}$ EDTA, $5 \mathrm{mM}$ 2-mercaptoethanol (dialysis buffer 1); $20 \mathrm{mM}$ MES pH 6.8, $10 \mathrm{mM}$ imidazole, $0.05 \%(\mathrm{w} / \mathrm{v})$ NLS, $5 \mathrm{mM}$ EDTA, $1 \mathrm{mM} 2-$ mercaptoethanol (dialysis buffer 2); 20 mM MES pH 6.0, 5 mM EDTA, 0.01\% (v/v) Triton X-100, 10\% (v/v) glycerol, $1 \mathrm{mM}$ 2-mercaptoethanol (storage buffer).

\section{Digestion of DsbA:HIV-1Pr with enterokinase}

Two different recombinant enterokinases from bovine intestine were used: from Sigma-Aldrich (Saint Louis, Missouri, USA) and from Novagen (Madison, Wisconsin, USA) at 0.02 and $50 \mathrm{U} / \mathrm{mg}$ fusion protein, respectively. The digestion reaction was carried out for $\sim 16$ hours (overnight) at $25^{\circ} \mathrm{C}$ in storage buffer (see above) to which $20 \mu \mathrm{M} \mathrm{CaCl}{ }_{2}$ was added.

\section{Purification of the GST:HIVPr fusion protein and PreScission protease cleavage}

The crude extract containing the various GST:HIVPr fusion proteins was loaded on a GSTrap column (GE Healthcare, Uppsala, Sweden) equilibrated in PBS, pH 7.4. The column was then extensively washed with the same buffer and subsequently equilibrated in PreScission buffer (50 mM TrisHCl pH 7.5, 10 mM EDTA, $0.15 \mathrm{M}$ $\mathrm{NaCl}$, and $1 \mathrm{mM}$ 2-mercaptoethanol) for the on-column cleavage procedure. PreScission protease was then loaded ( $70 \mu \mathrm{L}$ of a $2 \mathrm{U} / \mu \mathrm{L}$ solution, GE Healthcare), the column was immediately closed and incubated for 24 hours at $5^{\circ} \mathrm{C}$, followed by 2 hours at room temperature. The cleaved HIV-1Pr was then eluted in PreScission buffer.

After loading the crude extract, the GSTrap column was extensively washed in PBS pH 7.4 and then eluted with $50 \mathrm{mM}$ Tris $\mathrm{HCl} \mathrm{pH} 8.0$ containing $15 \mathrm{mM}$ reduced L-glutathione (Sigma Aldrich) for off-column PreScission protease cleavage (see above). The fusion protein was extensively dialyzed against PreScission buffer at $4^{\circ}$ $\mathrm{C}$, and then added of PreScission protease (20 U per mg of fusion protein). After incubation for 24 hours at $5^{\circ} \mathrm{C}$ followed by 2 hours at room temperature, the sample was loaded on a GSTrap column equilibrated in PreScission buffer, following the procedures described above. The eluted protein was dialyzed against the following buffers (1 hour each): $20 \mathrm{mM}$ MES pH 6.8, $5 \mathrm{mM}$ EDTA, $0.01 \%(\mathrm{v} / \mathrm{v})$ Triton-X 100, 5\% (v/v) glycerol, 1 mM 2-mercaptoethanol; $20 \mathrm{mM}$ MES pH 6.0, $5 \mathrm{mM}$ EDTA, $0.01 \%(\mathrm{v} / \mathrm{v})$ Triton X-100, 10\% (v/v) glycerol, 1 $\mathrm{mM}$ 2-mercaptoethanol (storage buffer).

\section{SDS-PAGE Electrophoresis and Western blot analysis}

Proteins from total cell extract or from both soluble and insoluble cell fractions were separated by SDS-PAGE. For total cell extracts and for insoluble fractions after cell disruption, cell pellets were directly resuspended in an appropriate volume of Laemmli sample buffer. For Western blot analysis, proteins were transferred electrophoretically onto a nitrocellulose membrane and the fusion protein was detected using anti-His-tag mouse monoclonal antibodies (His-probe, Santa Cruz Biotechnology, Santa Cruz, CA, USA) and goat anti-mouse IgG HRP-conjugated antibodies (Santa Cruz Biotechnology, 
Santa Cruz, CA, USA). Recognition was then demonstrated by a chemiluminescence method (ECL Plus Western Blotting Detection System, GE Healthcare, Uppsala, Sweden). His-Tagged D-amino acid oxidase was used as positive control [24].

\section{HIV-1Pr Activity assay and CD measurements}

A chromogenic substrate for HIV protease (substrate III, Bachem, Switzerland; with sequence H-His-Lys-Ala-ArgVal-Leu-Phe $\left(\mathrm{NO}_{2}\right)$-Phe-Glu-Ala-Nle-Ser- $\left.\mathrm{NH}_{2}\right)$ was dissolved in $100 \%$ DMSO to reach a concentration of 10 $\mathrm{mg} / \mathrm{mL}$. The assay was performed in $20 \mathrm{mM}$ sodium phosphate $\mathrm{pH}$ 6.0, $0.8 \mathrm{mM} \mathrm{NaCl}, 1 \mathrm{mM}$ EDTA, and 1 $\mathrm{mM}$ dithiothreitol (freshly added). Each measurement was performed by recording the absorbance at $310 \mathrm{~nm}$ with a Jasco V-560 spectrophotometer, at $25^{\circ} \mathrm{C}$, using cuvettes with a $3-\mathrm{mm}$ optical path. The total volume sample was $70 \mu \mathrm{L}$; activity was assayed on a $100 \mu \mathrm{M}$ substrate with a $10 \%$ DMSO final concentration. HIV1 Pr specific activity was calculated using the substrate extinction coefficient $500 \mathrm{M}^{-1} \mathrm{~cm}^{-1}$, as reported in [14].

Far-UV CD spectra were recorded in a Jasco J-815 spectrometer at $0.1 \mathrm{mg}$ protein $/ \mathrm{mL}$ and in storage buffer, as detailed in [25].

\section{Additional material}

Additional File 1: Supplementary HIV-1Pr.PDF. Supplementary text describes the expression trials using pET24b(+) or pET26b(+) plasmid. Figure S1 describes the amino acid sequence of the chimeric proteins and the mature HIV-1Pr used in this work. Figure S2 reports the growth curve of BL21-Codon Plus-(DE3)-RIL E. coli cells carrying the pET39-DsbA: HIV-1Pr plasmid in different media. Figure S3 reports the SDS-PAGE analysis of the purification of GST:HIV-1Pr protease fusion forms. Table S1 summarizes published results concerning the production of recombinant HIV-1Pr in different heterologous hosts.

\section{List of abbreviations}

DsbA: periplasmic E. coli dithiol oxidase; HIV-1Pr: aspartyl-protease encoded by HIV; IPTG: isopropyl- $\beta$-D-thiogalactopyranoside; NLS: N-lauroyl-sarcosine; GST: glutathione S-transferase.

\section{Acknowledgements}

This work was supported by grants from Fondo di Ateneo per la Ricerca to L. Pollegioni and L. Piubelli. We thank the support from Consorzio Interuniversitario per le Biotecnologie (CIB) and Centro di Ricerca in Biotecnologie per la Salute Umana. We are grateful to Gianluca Molla for the gene design and to Flavia Marinelli for helpful discussion.

\section{Author details}

'Dipartimento di Biotecnologie e Scienze Molecolari, Università degli Studi dell'Insubria, via J.H. Dunant 3, Varese, 21100, Italy. ${ }^{2}$ The Protein Factory, Centro Interuniversitario di Ricerca in Biotecnologie Proteiche, Politecnico di Milano and Università degli Studi dell'Insubria, via Mancinelli 7, Milano, 20131, Italy

\section{Authors' contributions}

LP conceived the project and wrote the paper. FV produced the expression plasmids, performed the overexpression trials, purified HIV-1Pr from DsbA: HIV-1Pr and GST:HIVPr precursors, analyzed the data and helped write the paper. LuPi performed expression experiments on the DsbA:HIV-1Pr, purified HIV-1Pr from the fusion partner, and helped write the paper. All authors have read and approved the final manuscript.

\section{Competing interests}

The authors declare that they have no competing interests.

Received: 19 April 2011 Accepted: 30 June 2011

Published: 30 June 2011

\section{References}

1. Hill M, Tachedjian G, Mak J: The packaging and maturation of the HIV-1 Pol proteins. Curr HIV Res 2005, 3:73-85.

2. Nutt RF, Brady SF, Darke PL, Ciccarone TM, Colton CD, Nutt EM, Rodkey JA, Bennett CD, Waxman LH, Sigal IS, Anderson PS, Veber DF: Chemical synthesis and enzymatic activity of a 99-residue peptide with a sequence proposed for the human immunodeficiency virus protease. Proc Natl Acad Sci USA 1988, 85:7129-7133.

3. Hui JO, Tomasselli AG, Reardon IM, Lull JM, Brunner DP, Tomich C-SC, Heinrikson RL: Large scale purification and refolding of HIV-1 protease from Escherichia coli inclusion bodies. J Protein Chem 1993, 12:323-327.

4. Hansen J, Billich S, Schulze T, Sukrow S, Moelling K: Partial purification and substrate analysis of bacterially expressed HIV protease by means of monoclonal antibody. EMBO J 1988, 7:1785-1791.

5. Karacostas V, Wolffe EJ, Nagashima K, Gonda MA, Moss B: Overexpression of the HIV-1 gag-pol polyprotein results in intracellular activation of HIV1 protease and inhibition of assembly and budding of virus-like particles. Virology 1993, 193:661-671.

6. Rizzo CJ, Korant BD: Genetic approaches designed to minimize cytotoxicity of retroviral protease. Methods Enzymol 1994, 241:16-29.

7. Wan M, Takagi M, Loh BN, Imanaka T: Comparison of HIV-1 protease expression in different fusion forms. Biochem Mol Biol Int 1995, 36:411-419.

8. Dergousova NI, Amerik AY, Volynskaya AM, Rumsh LD: HIV-I protease. Cloning, expression, and purification. Appl Biochem Biotech 1996 61:97-107.

9. Leuthardt A, Roesel JL: Cloning, expression and purification of a recombinant poly-histidine-linked HIV-1 protease. FEBS Lett 1993, 326:275-280.

10. Olins PO, Lee SC: Recent advances in heterologous gene expression in Escherichia coli. Curr Opin Biotechnol 1993, 4:520-525.

11. Komai T, Ishikawa $Y$, Yagi R, Suzuki-Sunagawa $H$, Nishigaki T, Handa $H$ : Development of HIV-1 protease expression methods using the T7 phage promoter system. Appl Microbiol Biotechnol 1997, 47:241-245.

12. Cheng YS, McGowan MH, Kettner CA, Schloss JV, Erickson-Viitanen S, Yin FH: High-level synthesis of recombinant HIV-1 protease and the recovery of active enzyme from inclusion bodies. Gene 1990, 87:243-248.

13. Gustafson ME, Junger KD, Foy BA, Baez JA, Bishop BF, Rangwala SH, Michener ML, Leimgruber RM, Houseman KA, Mueller RA, Matthews BK, Olins PO, Grabner RW, Hershman A: Large-scale production of HIV-1 protease from Escherichia coli using selective extraction and membrane fractionation. Protein Expr Purif 1995, 6:512-518.

14. Broglia RA, Provasi D, Vasile F, Ottolina G, Longhi R, Tiana G: A folding inhibitor of the HIV-1 protease. Proteins 2006, 62:928-933.

15. Louis JM, Clore GM, Gronenborn AM: Autoprocessing of HIV-1 protease is tightly coupled to protein folding. Nature Struct Biol 1999, 6:868-875.

16. Egan SM, Schleif RF: A regulatory cascade in the induction of rhaBAD. $J$ Mol Biol 1993, 234:87-98.

17. Haldimann A, Daniels L, Wanner B: Use of new methods for construction of tightly regulated arabinose and rhamnose promoter fusions in studies of the Escherichia coli phosphate regulon. J Bacteriol 1998, 180:1277-1286

18. Zwietering $M H$, Jongenburger I, Rombouts FM, van't Riet $\mathrm{K}$ : Modeling of the bacterial growth curve. Appl Environ Microbiol 1990, 56:1875-1881.

19. Schein $\mathrm{CH}$ : Production of soluble recombinant proteins in bacteria. BioTechnology 1989, 7:1141-1148.

20. Molla G, Bernasconi MG, Sacchi S, Pilone MS, Pollegioni L: Expression in Escherichia coli and in vitro refolding of the human protein pLG72. Protein Expr Purif 2006, 46:150-155.

21. Worsdorfer B, Woycechowsky KJ, Hilverd D: Directed evolution of a protein container. Science 2011, 331:589-592. 
22. Volontè F, Marinelli F, Gastaldo G, Sacchi S, Pilone MS, Pollegioni L, Molla G: Optimization of glutaryl-7-aminocephalosporanic acid acylase expression in E. coli. Prot Express Purif 2008, 61:131-137.

23. Volontè F, Pollegioni L, Molla G, Frattini L, Marinelli F, Piubelli L: Production of recombinant cholesterol oxidase containing covalently bound FAD in Escherichia coli. BMC Biotech 2010, 10:33.

24. Fantinato S, Pollegioni L, Pilone MS: Engineering, expression and purification of a His-tagged chimeric D-amino acid oxidase from Rhodotorula gracilis. Enzyme Microb Technol 2005, 29:407-412.

25. Caldinelli L, lametti S, Barbiroli A, Bonomi F, Fessas D, Molla G, Pilone MS, Pollegioni L: Dissecting the structural determinants of the stability of cholesterol oxidase containing covalently bound flavin. J Biol Chem 2005, 280:22572-22581.

doi:10.1186/1475-2859-10-53

Cite this article as: Volontè et al:: Optimizing HIV-1 protease production

in Escherichia coli as fusion protein. Microbial Cell Factories 2011 10:53.

\section{Submit your next manuscript to BioMed Central} and take full advantage of:

- Convenient online submission

- Thorough peer review

- No space constraints or color figure charges

- Immediate publication on acceptance

- Inclusion in PubMed, CAS, Scopus and Google Scholar

- Research which is freely available for redistribution

Submit your manuscript at www.biomedcentral.com/submit
C Biomed Central 